\title{
Historical Review of Waste Management and Recycling in South Africa
}

\author{
Linda Godfrey ${ }^{1,2, *}$ (i) and Suzan Oelofse ${ }^{2,3}$ \\ 1 CSIR Implementation Unit, P.O. Box 395, Pretoria 0001, South Africa \\ 2 Unit for Environmental Sciences and Management, North-West University, Potchefstroom 2520, \\ South Africa; SOelofse@csir.co.za \\ 3 CSIR Natural Resources and the Environment, P.O. Box 395, Pretoria 0001, South Africa \\ * Correspondence: LGodfrey@csir.co.za; Tel.: +27-128-414-801
}

Received: 11 September 2017; Accepted: 13 October 2017; Published: 19 October 2017

\begin{abstract}
Recycling has been taking place in South Africa for more than three decades, driven by social and economic needs. While the waste hierarchy is embedded in national policy, an extensive legislative framework has made it more and more challenging for the public and private sector to remain compliant and competitive in a local and global market, and still drive waste away from landfill towards reuse, recycling and recovery. A local recycling economy, on par with many developed countries, is in part due to a large and active informal waste sector. In the absence of separation at source across South African cities and towns, informal waste pickers have been key to accessing resources which the private sector has struggled to access, due to gatekeeping by municipalities. The South African waste and recycling sector can be defined in terms of four main stages of development- "The Age of Landfilling", "The Emergence of Recycling", "The Flood of Regulation" and "The Drive for EPR", and is currently standing on the brink of a fifth stage- "The future is a Circular Economy". The low hanging fruit, the easy to collect and recycle products, has been reaped. Moving to higher diversion from landfill targets will require more investment by the private sector and by government in the future. The social, economic and environmental benefits of doing this are clear, but must be balanced against the cost that will ultimately be borne by society, as consumers.
\end{abstract}

Keywords: waste; recycling; informal sector; legislation; South Africa

\section{Introduction}

It is often said that South Africa is 20-30 years behind Europe (and other developed countries) in the management of waste and the shift away from landfilling towards prevention, reuse, recycling and recovery. This paper will show, that in spite of (or because of) this lag, Europe has had a strong influence on the policy and legislation that has emerged in South Africa since the late 1990's. While the majority of waste generated in South Africa (90\%) continues to be sent to landfill for disposal [1], this lag in development presents an opportunity for South Africa to learn from what other countries have implemented (policy and technology), and both succeeded and failed at, and domesticate this learning for the local sector. This paper presents a brief history of waste management and recycling in South Africa since the late 1980s; the shifts which have occurred over this period; the emergence of integrated waste management; and more recently the appearance of the "circular economy" in the discourse of government, industry and academia. 


\section{Waste and Recycling in South Africa}

In reviewing the development of waste management and recycling in South Africa, it is useful to reflect on the policy and regulatory environment. As this context provides a useful framework from which to identify the stages that have shaped the sector over the past 30 years, and the key milestones which have acted as triggers for change in the sector. A summary of waste policy and legislation in South Africa from 1989 to 2017 (as at the time of writing) is presented in Figure 1, accompanied by a brief description of major legislation which has been promulgated by the South African government.

\subsection{Overview of Waste Policy and Regulation}

The story starts with the Environmental Conservation Act (Act 73 of 1989) [2] as amended. It set out the requirements for the management of waste and provided the first legal definition of waste. But, it was largely focused on the permitting, control and management of waste disposal sites. The intention being to reduce the environmental impacts associated with many poorly operated landfills, many of which were in fact dumpsites (controlled and uncontrolled). It did however, acknowledge that the Minister of Environmental Affairs and Tourism (DEAT) could make regulations with regards to the reduction, reuse and recovery of waste, although this instrument was never utilised. Limited waste policy and regulation emerged between 1989 and 2007. With the publishing of the 1st National Waste Management Strategy (NWMS) [3] and the White Paper on Integrated Pollution and Waste Management (IP\&WM) [4], the stage was set for what was to follow. In 2008, the National Environmental Management (NEM): Waste Act (Act 59 of 2008) [5] was promulgated, which created the impetus for a flurry of regulation that followed between 2008 and 2017, including the NEM: Waste Amendment Act (Act 26 of 2014) [6].

\subsection{The Stages of a South African Waste Economy}

Mapping the waste legislative context in South Africa, allowed the authors to identify four stages through which the South African waste and recycling sector has transitioned over the past three decades. The first, termed "The Age of Landfilling", is a period starting in 1989 and from which, one might argue, South Africa has not yet emerged. The second stage, is "The Emergence of Recycling" which started in 2001 with the publication of the Polokwane Declaration and the lead up to the banning of single-use plastic bags. Since 2001, a waste recycling economy has emerged in South Africa, but as the last official waste statistics show, the country has only been able to divert $10 \%$ of the waste generated away from landfill towards recycling [1]. We argue that recycling is still far from maturity in South Africa. The third stage, is "The Flood of Regulation", a period starting in 2008 with the promulgation of the NEM: Waste Act (Act 59 of 2008) [5]. As shown in Figure 1, what resulted was a wave of new waste legislation and regulations aimed at largely controlling the waste and secondary resources sector. The fourth stage, is "The Drive for EPR", which started in 2012 with the publication of the Integrated Industry Waste Tyre Management Plan (IIWTMP). The IIWTMP, managed by a Producer Responsibility Organisation, was aimed at fulfilling tyre producers' responsibilities for end-of-life waste tyres, through a mandatory Extended Producer Responsibility (EPR) scheme [7]. Each of these phases in the South African waste landscape, are discussed briefly below. 


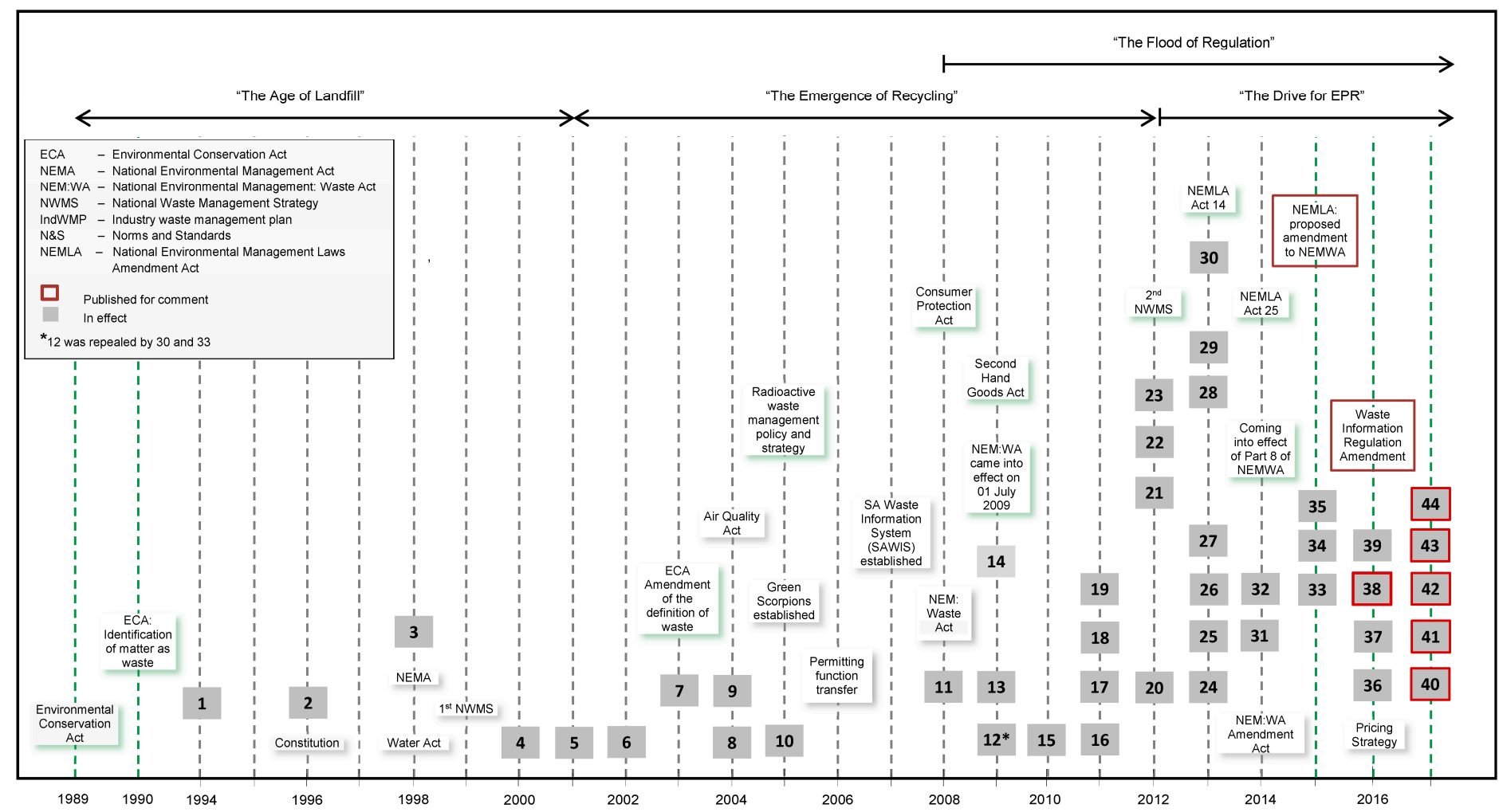

\begin{tabular}{|c|c|c|c|c|c|c|c|c|c|}
\hline & Minimum Requirements Edition 1 & 10 & $\begin{array}{l}\text { Glass Memorandum of } \\
\text { Agreement }\end{array}$ & 19 & $\begin{array}{l}\text { Domestic Waste Collection } \\
\text { Standards }\end{array}$ & 28 & $\begin{array}{l}\text { Norms \& Standards: Assessment of waste for } \\
\text { landfill Disposal }\end{array}$ & 37 & $\begin{array}{l}\text { Notice: IItention to require waste transporters to } \\
\text { register on SAWS }\end{array}$ \\
\hline 2 & \begin{tabular}{|l} 
Green Paper Environmental \\
Policy
\end{tabular} & 11 & Asbestos Regulation & 20 & Municipal Solid Waste Tariff Strategy & 29 & Amendment to Plastic Bag Levy & 38 & Dangerous Goods Standards \\
\hline & Minimum Requirements Edition 2 & 12 & $\begin{array}{l}\text { List of Waste Management } \\
\text { Activities, } 2009\end{array}$ & 21 & Redisa Tyre IndWMP & 30 & $\begin{array}{l}\text { List of Waste Management Activities Regulation, } \\
2013\end{array}$ & 39 & $\begin{array}{l}\text { Notice: Intention to call for P\&P, WEEE and } \\
\text { LightinglndwWPS }\end{array}$ \\
\hline & $\begin{array}{l}\text { White Paper Integrated Pollution } \\
\text { and Waste Management }\end{array}$ & 13 & Waste Tyre Regulations & 22 & Waste Information Regulations & 31 & $\begin{array}{l}\text { Norms \& Standards: Remediation of } \\
\text { Contaminated Land }\end{array}$ & 40 & Amendment list of waste management activities \\
\hline & Polokwane Declaration & 14 & Policy Thermal Treatment & 23 & Municipal Waste Sector Plan & 32 & 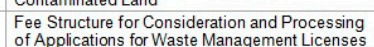 & 41 & 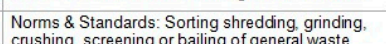 \\
\hline & $\begin{array}{l}\text { Plastic Memorandum of } \\
\text { Agreement and regulation }\end{array}$ & 15 & Policy Economic Instruments & 24 & $\begin{array}{l}\text { Norms \& Standards: Extraction and } \\
\text { Flaring of Landfill Gas }\end{array}$ & 33 & $\begin{array}{l}\text { Liftopic Waste Management Activities Regulation, } \\
2015\end{array}$ & 42 & $\begin{array}{l}\text { Notice: Tyre industry to prepare and submit } \\
\text { IndWMP. }\end{array}$ \\
\hline & $\begin{array}{l}\text { Plastic Carrier bags and flat bag } \\
\text { regulations }\end{array}$ & 16 & Amendment to Plastic Bag Levy & 25 & $\begin{array}{l}\text { Norms \& Standards: Scrapping of } \\
\text { motorvehicles }\end{array}$ & 3 & Admission Of Guilt Fine Regulations, 2015 & 43 & $\begin{array}{l}\text { Consultation on intention to consider withdrawal of } \\
\text { REDISA Tyre Plan }\end{array}$ \\
\hline & Gauteng Waste Regulations & 17 & Model Waste By-Law & 26 & $\begin{array}{l}\text { Norms \& Standards: Storage of } \\
\text { waste }\end{array}$ & 35 & $\begin{array}{l}\text { Residue Stockpiles And Residue Deposits } \\
\text { Regulations }\end{array}$ & 44 & $\begin{array}{l}\text { Proposed regulations to exclude waste streams } \\
\text { from definition }\end{array}$ \\
\hline & $\begin{array}{l}\text { National Waste Management } \\
\text { Strateay Ymolementatition }\end{array}$ & 18 & $\begin{array}{l}\text { Refuse Removal Services: } \\
\text { Indigent Households }\end{array}$ & 2 & $\begin{array}{l}\text { Waste Classification and } \\
\text { Waste Clanent Regulations }\end{array}$ & 36 & Waste Tyre Regulations Amendment & & \\
\hline
\end{tabular}

Figure 1. Changing waste policy landscape in South Africa (adapted from [8,9]). 


\section{3. "The Age of Landfilling"}

Landfilling of general and hazardous waste remains the dominant technology solution in South Africa, with an estimated $90 \%$ of all waste generated in South Africa disposed of to landfill [1]. This is typical of waste management in developing countries, where disposal of waste, often to uncontrolled dumpsites, dominates [10]. A number of environmental and human health concerns associated with landfills, prompted Government to develop policy and regulations aimed at improving the way in which landfills were designed and operated. This phase was marked by the Environmental Conservation Act (Act 73 of 1989, as amended) and the Minimum Requirements document series, published by the Department of Water Affairs and Forestry (DWAF) in 1994 and updated in 1998 [11,12]. The Minimum Requirements documents, which provided technical guidance for the handling, classification and disposal of waste, was developed with funding and technical support from the Danish Cooperation for Environment and Development (DANCED). The Minimum Requirements were replaced by "National Norms and Standards for the Assessment of Waste for Landfill Disposal" [13] and the "National Norms and Standards for Disposal of Waste to Landfill" [14].

Historically, South Africa has operated a large number of landfill sites, most of which were unlicensed. A study undertaken by DEA between 2007 and 2009, showed that, of the 581 waste disposal facilities identified, 431 (74\%) were not licensed [15]. National government embarked on a process to get all landfill sites permitted, by assisting Municipalities and funding the authorisation of unlicensed landfill sites between 2013 and 2016 (at a cost of US\$2.44 million) [16]. This has resulted in a significant turnaround in the licence status of landfills in South Africa, although compliance with licence conditions remains unclear [16].

Landfilling remains the dominant technology choice for general and hazardous waste in South Africa. This is driven by low landfill gate fees; unwilling municipalities and waste generators to find alternative solutions; and (until recently) the plenitude of space in South Africa. Typical municipal landfill gate fees of around $€ 10-15 /$ tonne are an order of magnitude cheaper than what one might find in Europe. A few municipalities now face serious landfill airspace shortages, and have increased their gate fees to around $€ 25-40 /$ tonne. These low gates fees make it very difficult to implement alternative waste treatment technologies economically. The disposal of certain waste streams, such as clean builders rubble or garden waste at landfills, is often free, as a means of combatting the high levels of illegal dumping within cities.

\section{4. "The Emergence of Recycling"}

Recycling has been taking place in South Africa for many decades, driven mostly by social needs and to a limited extent, the demand for certain resources. Steelrec, the predecessor to Collect-a-Can which supports the collection and recycling of used beverage cans in South Africa, was established as far back as 1976 by Metal Box and Crown Cork (the predecessors of Nampak and ArcelorMittal) [17,18]. Waste sorting facilities in major urban areas in Johannesburg and Pretoria were already noted in the 1970's [19]. A paper recovery rate of $23 \%$ for South Africa was reported in 1973 [20]. However, as noted by Collect-a-Can [18], local end-use markets were limited in the 1970's, resulting in the stockpiling of beverage cans.

Government's intentions with regards to driving greater waste recycling were charted with the publication of the White Paper on IP\&WM [4] and the 1st NWMS [3]. As with the Minimum Requirements, these policy documents were developed with technical support and funding from the Danish Cooperation for Environment and Development (DANCED). It wasn't until the first National Waste Management Summit, and the publication of the Polokwane Declaration in 2001 (aimed at mapping South Africa's transition towards zero waste), that targets for recycling were set and ratified by government (noting not all national departments), business and civil society [21]. However, as stressed by Oelofse and Strydom [22] (p. 2), these targets "were not legislated and have become a contentious issue within the South African waste sector". 
DEAT published two guidelines aimed at assisting municipalities in implementing the 1st NWMS. The Guidelines, entitled "Working with waste: Guidelines on waste collection in high density and unserviced areas" and "Working with waste: Guidelines for recycling" [23,24] were funded with the support of the Danish International Development Agency (DANIDA). As noted in the foreword of the Guidelines "The focus of waste management in South Africa is changing. No longer is the emphasis on the disposal of waste, but rather on avoiding its generation and minimising the waste stream wherever possible." [23,24] (p. ii). This was soon followed by the banning of single-use, lightweight plastic bags in 2003 and the implementation of a plastic bag tax, aimed at minimising the volume of plastic bags littering the South African landscape [25].

What followed since 2001, was the growth of a local waste recycling economy, driven by (i) industry efforts to pre-empt possible government regulatory action, on the belief that it could develop and implement more effective, sustainable and lower cost solutions than government imposed regulations; (ii) voluntary investment by producers and manufacturers; and (iii) economics, as a competitive response to other materials [22]. Voluntary material organisations such as the PET Recycling Company (PETCO), and The Glass Recycling Company (TGRC) emerged, providing further impetus to the collection and recycling of packaging recyclables. Since multi-national companies such as Coca-Cola were involved in these original initiatives, playing a leadership role for example, in the establishment of PETCO [26], one can argue that approaches to the management of end-of-life products adopted in Europe or the USA, would have had a strong influence on the design of local South African recycling solutions and operational structures. These voluntary materials organisations have had a significant influence on the South African recycling landscape. With its name change and re-launch in 1993, Collect-a-Can has increased beverage can collection rates from $18 \%$ in 1993 to $72 \%$ in 2015 [27]. Since the establishment of PETCO, post-consumer PET bottle recycling has increased from $16 \%$ in 2005 to $55 \%$ in 2016 [28]. The collection ("input") of paper and packaging recyclables in South Africa overall, has grown from $41.6 \%$ in 2007 to $57.1 \%$ in 2015 [29,30] (Figure 2).

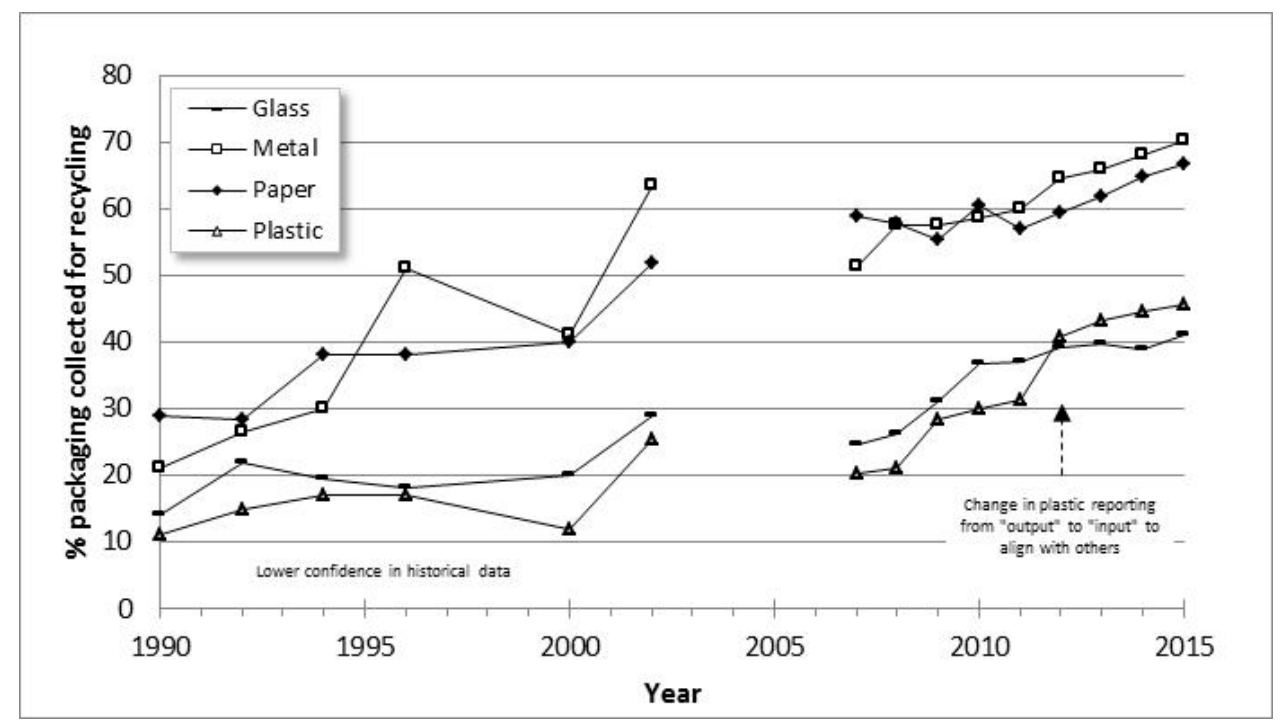

Figure 2. Paper and packaging collection rates (adapted from [22,31]) (data reflected as "input" (collection), except plastic pre-2012 which is "output" (recycling).

With no separation at source yet in place across South African cities and towns, this level of recycling, in line with many developed countries, has been largely due to an active and growing informal waste sector. Available data suggests that the South African informal sector is responsible for the collection of $80-90 \%$ (by weight) of the post-consumer paper and packaging recovered for recycling, saving municipalities between R309.2-R748.8 million in landfill airspace (in 2014), at little to 
no cost [32]. The informal sector has therefore been very successful in bridging the service and value chains (Figure 3) in spite of little to no integration into municipal waste management services.

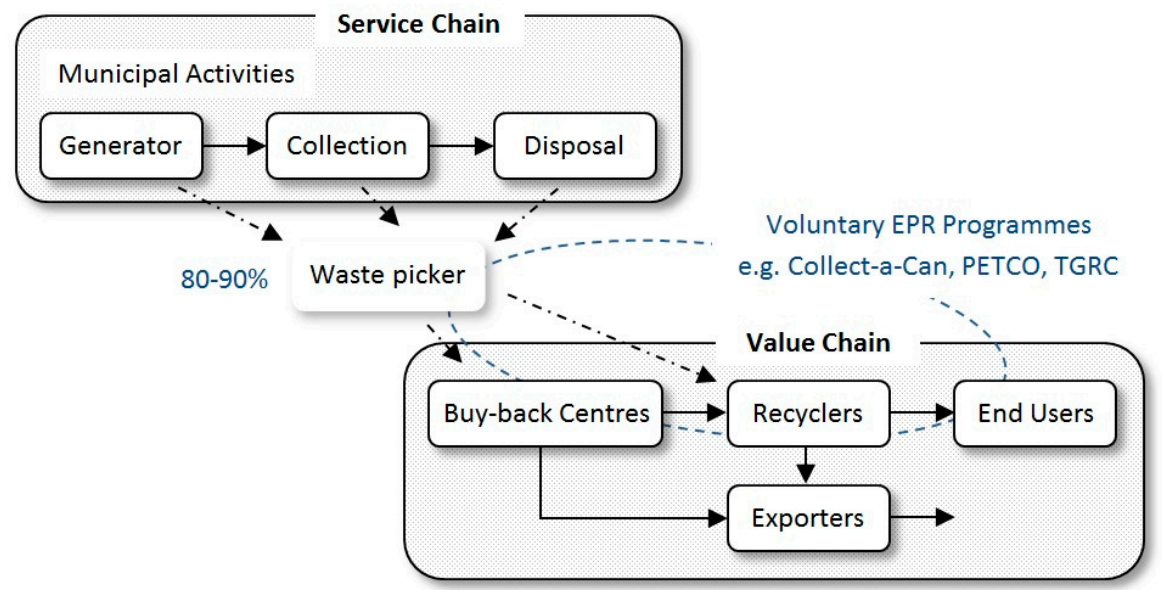

Figure 3. Role of the informal waste picker in bridging the service- and value-chains in South Africa (with a focus on paper and packaging) (adapted from [33]).

The South African government estimates that there are between 60,000-90,000 informal waste pickers working either at kerbside or on landfills in South Africa [34,35]. These numbers may, however, be conservative. If one assumes that the findings of Linzner and Lange [36] apply to South Africa-that informal waste pickers account for approximately $0.6 \%$ of the urban population-then there could be as many as 215,000 informal waste pickers earning a livelihood from waste in South Africa. The visible increase in the number of informal waste pickers over the past few years has been partly due to the increase in unemployment in South Africa, which has forced people to seek a livelihood in the informal sector.

The South African government has actively promoted co-operatives as a means of formalising the informal sector, and stimulating job creation and enterprise development. However, waste and recycling co-operatives have suffered from a very high failure rate in South Africa, at 91.8\% [37]. Co-operatives in South Africa face numerous challenges including the lack of "infrastructure", such as a lack of access to transport, equipment, or premises at which to sort and store recyclables. Further, "operational" challenges such as difficulty in accessing markets or theft of recyclables, and weak "capability" to operate a business, were found to hamper successful implementation. It is also evident that some co-operatives are in fact operating as traditional businesses (e.g., following Pty Ltd business models) with the five co-operative members (the minimum required membership for registering a co-operative) taking on management roles and employing staff to collect and sort recyclables [38,39]. Numerous initiatives and research projects are underway in South Africa to find appropriate solutions to integrate the informal waste sector into the local waste economy.

At the transition of this stage to the next, South Africa had only been able to divert $10 \%$ of all waste generated, away from landfill towards recycling (as at 2011) [1]. There is still much to be done in strengthening the local recycling economy, and we argue that a secondary resource economy is still far from maturity in South Africa. However, the waste and secondary resources sector has been identified in national strategy and policy documents as a sector which can contribute towards South Africa's economic growth and the creation of green jobs [40-46].

\section{5. "The Flood of Regulation"}

The stage for waste legislation was set with the publication of the White Paper on IP\&WM [4]. However, it wasn't until eight years later, that the first waste legislation, the NEM:WA (Act 59 of 2008) [5] was published. NEM:WA provided the mechanism to regulate every aspect of the waste 
and secondary resources value chain in South Africa. What followed was a flood of regulation aimed at "controlling" the sector in an effort to minimise the environmental and human health impacts associated with poor waste management, while at the same time, striving to drive waste up the hierarchy away from disposal towards reuse, recycling and recovery.

However, this has resulted in an environment in which waste reuse, recycling and recovery activities have become extremely difficult to implement, without triggering extensive legislative requirements. Even the legal definition of waste, as a protection based definition, is considered by many to have hindered the drive towards reuse, recycling and recovery [47]. Concerns have been raised by business that legislation has become a major constraint to the growth of a recycling economy in South Africa $[9,34,48]$.

In addition to the specific waste legislation outlined in Figure 1, the authors have identified a further 41 National Acts that have a direct or indirect bearing on waste management in South Africa [49]. This is further compounded by provincial and municipal waste legislation, such as specific municipal bylaws. This flood of waste regulation over the past decade has placed a huge burden on the private sector to keep pace with ever changing regulatory requirements and ensure compliance and legal operations. A major concern of industry is the growing cost of compliance with legislation while trying to remain competitive in a local and international market.

\section{6. "The Drive for EPR"}

With a strong, historical command-and-control approach to waste management, the next stage was ushered in with the emergence of alternative policy instruments, in particular economic instruments. While both incentives and disincentives have been provided for in recently published legislation [50] their appears to be a strong leaning by Government towards punitive economic instruments, such as product taxes, EPR taxes and (under discussion) landfill taxes. This has raised concerns by industry, that these measures are more about raising money for the national fiscus, than driving and incentivising a secondary resources economy in South Africa. EPR is under consideration by a number of developing countries, desperate to find alternative ways of funding basic waste management services, as well as growing a secondary resources economy in an effort to drive job creation and enterprise development [10,33].

As noted previously, South Africa has had voluntary material organisations in place since the mid-2000s, many of them implementing aspects of EPR and operating along similar lines to a Producer Responsibility Organisation (PRO). However, it was only following the promulgation of the NEM: Waste Act (Act 56 of 2008) [5], that the legal framework created the opportunity to move from voluntary to mandatory EPR schemes. The promulgation of the Waste Tyre Plan in 2012 [7] marked the start of mandatory EPR in South Africa. However, this waste tyre EPR scheme has been plagued by concerns from Government, Labour and Civil Society over the past five years. This culminated in Government gazetting legislation that shifted the EPR "fee", previously collected by the PRO, to an EPR "tax", which is now paid by producers directly to Government [51,52]; and calling for additional waste tyre industry waste management plans (EPR schemes) [53].

Further, Government has made its intentions clear in calling for EPR schemes for paper and packaging, waste electrical and electronic equipment (WEEE) and lighting. While this has been under discussion since 2014, it remains uncertain as to when Government will officially call for these Industry Waste Management Plans. This has created great uncertainty in the recycling sector as well as amongst the voluntary material organisations. However, the promise of EPR also provides significant opportunities to further grow and finance a secondary resources economy in South Africa, by raising additional funding necessary to extend collection and local end-use markets for negative value products. 


\section{Discussion and Conclusions}

South Africa has successfully grown a recycling economy over the past three decades, partly built on the hard work of an active informal waste sector. It is acknowledged, that there is still much to be done, given that significant quantities of waste, including recyclables, are still disposed of to landfill. Using the policy and regulatory environment as a framework, four stages in the history of the South African waste and recycling sector can be identified-“The Age of Landfilling", "The Emergence of Recycling", "The Flood of Regulation" and "The Drive for EPR". South Africa has a policy environment that actively promotes the diversion of waste away from landfill through prevention, reuse, recycling and recovery. However, the response to this policy has been slow, with only $10 \%$ of all general and hazardous waste generated in 2011 being diverted from landfill [1]. While no official statistics exist since 2011, it is expected that progress has been made in growing the local recycling economy. However, landfilling, often to open dumpsites, remains the dominant technology solution for managing waste in South Africa. Because of this, Government has made its intentions clear to grow the waste and secondary resources sector from $0.51 \%$ of GDP to between $1.0-1.5 \%$ of GDP, as a means of contributing towards the larger challenges facing South Africa of poverty, unemployment and inequality [34].

Through funding and technical expertise provided by international donor agencies, developed countries have had a perceptible influence on the South African waste and recycling landscape. However, progress remains slow, particularly for non-packaging waste streams such as organic waste (including industrial biomass), construction and demolition (C\&D) waste, and other bulky waste streams such as mining residues and power generation waste. While Government has identified EPR as the mechanism to fund increased recycling, job creation and enterprise development in the paper and packaging, electronic waste, lighting and tyre sectors, mechanisms must also be found to drive the beneficiation of other waste streams where the "producer" may not be as clear.

Unlocking the social, economic and environmental opportunities provided by secondary resources has the potential to create significant opportunities. South Africa, as with the rest of the world, is standing on the brink of a new fifth, and global, phase "The future is a Circular Economy". The question facing us is how do we domesticate and commercialise a circular economy in a developing country context, such as South Africa? This is highly relevant as South Africa moves towards implementation of alternative waste treatment technologies. There is the temptation for South Africa to follow exactly the same path that European countries have followed in managing their waste. In particular, to push forward with the implementation of high temperature waste-to-energy solutions such as incineration, pyrolysis or gasification. With the fervour emerging over the circular economy, and likely shift away from high temperature WtE solutions, we ask, "Is there an opportunity for South Africa, and other developing countries, to leapfrog the technology choices of developed countries, and move directly towards a stronger materials recovery paradigm?"

Author Contributions: Linda Godfrey and Suzan Oelofse, both authors contributed technically to this paper.

Conflicts of Interest: The authors declare no conflict of interest.

\section{References}

1. DEA (Department of Environmental Affairs). National Waste Information Baseline Report; DEA: Pretoria, South Africa, 2012. Available online: http:/ / sawic.environment.gov.za/documents/1880.pdf (accessed on 2 October 2017).

2. Republic of South Africa. Environment Conservation Act 73 of 1989. Government Gazette No. 11927, Notice No. 1188. 1989. Available online: https:/ / www.environment.gov.za/sites/default/files/legislations/ environment_conservation_act73of1989.pdf (accessed on 2 October 2017).

3. Department of Environmental Affairs and Tourism (DEAT). National Waste Management Strategies and Action Plans South Africa; Strategy Formulation Phase. National Waste Management Strategy, Version D; DEAT: Pretoria, South Africa, 15 October 1999. 
4. DEAT (Department of Environmental Affairs and Tourism). White Paper on Integrated Pollution and Waste Management for South Africa. A Policy on Pollution Prevention, Waste Minimisation, Impact Management and Remediation. Government Gazette No. 20978, Notice No. 227. 2000. Available online: https:/ /www. environment.gov.za/sites/default/files/legislations/integrated_pollutionand_wastemanagement_0.pdf (accessed on 2 October 2017).

5. Republic of South Africa. National Environmental Management: Waste Act 59 of 2008. Government Gazette No. 32000, Notice No. 278. 2009. Available online: https:/ / www.environment.gov.za/sites/default/files/ legislations/nema_amendment_act59.pdf (accessed on 2 October 2017).

6. Republic of South Africa. National Environmental Management: Waste Amendment Act 26 of 2014. Government Gazette No. 36784, Notice No. 449. 2014. Available online: https://www.environment. gov.za/sites/default/files/legislations/nemwa_actno26of2014.pdf (accessed on 2 October 2017).

7. Republic of South Africa. Integrated Industry Waste Tyre Management Plan of the Recycling and Economic Development Initiative of South Africa (REDISA), Government Gazette No. 35927, Notice No. 988. 2012. Available online: http:/ / sawic.environment.gov.za/documents/1702.PDF (accessed on 2 October 2017).

8. Godfrey, L.; Nahman, A. Are developing countries ready for first world waste policy instruments? In Proceedings of the Sardinia Conference, Eleventh International Waste Management and Landfill Symposium, S. Margherita di Pula, Cagliari, Italy, 1-5 October 2007. Available online: http:/ / researchspace. csir.co.za/dspace/handle/10204/846 (accessed on 2 October 2017).

9. DST (Department of Science and Technology). A National Waste R\&D and Innovation Roadmap for South Africa: Phase 1 Status Quo Assessment. In Current and Required Institutional Mechanisms to Support Waste Innovation; Department of Science and Technology: Pretoria, South Africa, 2012. Available online: http:/ / wasteroadmap.co.za/download/report_support_waste_innovation.pdf (accessed on 2 October 2017).

10. UNEP (United Nations Environment Programme). Global Waste Management Outlook. 2015. Available online: http://www.unep.org/ourplanet/september-2015/unep-publications/global-wastemanagement-outlook (accessed on 2 October 2017).

11. DWAF (Department of Water Affairs \& Forestry). Waste Management Series. In Minimum Requirements for the Handling, Classification and Disposal of Hazardous Waste, 2nd ed.; Document 1; DWAF: Pretoria, South Africa, 1998.

12. Department of Water Affairs \& Forestry (DWAF). Waste Management Series. In Minimum Requirements for Waste Disposal by Landfill, 2nd ed.; Document 2; DWAF: Pretoria, South Africa, 1998.

13. Republic of South Africa. National Norms and Standards for the Assessment of Waste for Landfill Disposal. Government Gazette No. 32000, Notice No. 635. 2013. Available online: https://www.environment. gov.za/sites/default/files/legislations/nemwa59of2008_norms_standards_forassessment.pdf (accessed on 2 October 2017).

14. Republic of South Africa. National Norms and Standards for Disposal of Waste to Landfill. (RSA, 2013b). Government Gazette No. 36784, Notice No. 636. 2013. Available online: https:/ /www.environment.gov. $\mathrm{za} /$ sites/default/files/gazetted_notices/nemwa59of2008_norms_standards_fordisposa.pdf (accessed on 2 October 2017).

15. Pienaar, R.A.; Howard, M. From 50 dump sites to 50 waste disposal facilities—challenges and lessons learnt. In Proceedings of the 20th WasteCon Conference, Somerset West, Cape Town, South Africa, 6-10 October 2014. Available online: http:/ / www.infrastructurene.ws/wp-content/uploads/sites/4/2015/09/Pienaar-R.A. -and-Howard-M.-88.pdf (accessed on 2 October 2017).

16. DEA (Department of Environmental Affairs). Status of waste landfill sites in South Africa, 2016. Presentation to the Portfolio Committee. 2016. Available online: http:/ / pmg-assets.s3-website-eu-west-1.amazonaws. com/160915presentation.pdf (accessed on 25 July 2017).

17. Nampak. Nampak Limited Annual Report 2002. Available online: www.nampak.co.za (accessed on 20 May 2010).

18. Collect-a-Can. A Walk through History with Collect-a-Can. March 2011. Available online: http: / / collectacan.co.za/index.php?option=com_content\&view=article\&id=128:march-2011-a-walk-throughhistory-with-collect-a-can\&catid=5:junepres (accessed on 29 July 2017). 
19. Noble, R.G. Solid Waste Research in South Africa; South African National Scientific Programmes Report No. 4; Council for Scientific and Industrial Research: Pretoria, South Africa, June 1976. Available online: http:/ / researchspace.csir.co.za/dspace/bitstream/handle/10204/2236/SANSP\%20004\% 20.pdf? sequence=1\&isAllowed=y (accessed on 18 October 2017).

20. Brooks, G.R. Disposal and Recovery of Waste paper in South Africa; South African National Scientific Programmes Report No. 13; Council for Scientific and Industrial Research: Pretoria, South Africa, April 1977. Available online: http:/ / researchspace.csir.co.za/dspace/bitstream/handle/10204/2219/SANSP\%20013. pdf? sequence $=1$ \&isAllowed $=y$ (accessed on 18 October 2017).

21. DEAT (Department of Environmental Affairs and Tourism). Polokwane Declaration on Waste Management. 2001. Available online: http://soer.deat.gov.za/dm_documents/polokwane_nmZiT.pdf (accessed on 28 June 2017).

22. Oelofse, S.H.H.; Strydom, W.F. The trigger to recycling in a developing country-In the absence of command-and-control instruments. In Proceedings of the Conference Waste 2010: Waste and Resource Management-Putting Strategy into Practice, Stratford-upon-Avon, Warwickshire, UK, 28-29 September 2010. Available online: https:/ / researchspace.csir.co.za/dspace/bitstream/handle/10204/ 4702/Oelofse5_2010.pdf?sequence=1 (accessed on 2 October 2017).

23. DEAT (Department of Environmental Affairs and Tourism). Working with Waste: Guideline on Waste Collection in High Density and Un-Serviced Areas; Department of Environmental Affairs and Tourism: Pretoria, South Africa, 2001.

24. DEAT (Department of Environmental Affairs and Tourism). Working with Waste: Guideline on Recycling of Solid Waste; Department of Environmental Affairs and Tourism: Pretoria, South Africa, 2001.

25. Republic of South Africa. Regulations under Section 24 (d) of the Environment Conservation Act (Act No 73 of 1989)_Plastic Carrier Bags and Plastic Flat Bags; Government Gazette No. 24839, Notice No. 625; 9 May 2003. Available online: https:/ / www.gov.za/sites/default/files/24839_0.pdf (accessed on 18 October 2017).

26. Scholtz, C. (PETCO, South Africa). Personal communication, 20 July 2017.

27. Collect-a-Can. South Africa: Beverage Can Recovery Rate 1993 to 2015. Available online: http:/ / www. collectacan.co.za/index.php/can-recycling/recovery-rate (accessed on 29 July 2017).

28. PETCO. Future Focus. A Review of PETCO Activities. 2016. Available online: http://petco.co.za/wpcontent/uploads /2017 / 05 / PETCO-2016-Annual-Review_web-version.pdf (accessed on 28 July 2017).

29. BMi Research. Recycle Assessments; Prepared by BMi Research for RAG Members; BMi Research: Pretoria, South Africa, 2009.

30. BMi Research. Packaging South Africa Report; BMi Research: Pretoria, South Africa, 2016.

31. PackagingSA. Packaging Material Collected for Recycling. 2012-2015. Updated 1 October 2016.

32. Godfrey, L.; Strydom, W.; Phukubye, R. Integrating the Informal Sector into the South African Waste and Recycling Economy in the Context of Extended Producer Responsibility; CSIR Briefing Note: Pretoria, South Africa, 2016.

33. OECD. Working Party on Resource Productivity and Waste. In Extended Producer Responsibility-Updated Guidance; ENV/EPOC/WPRPW(2015)16/FINAL; OECD: Paris, France, 2016.

34. DST (Department of Science and Technology). South African Waste Sector-2012. An analysis of the formal private and public waste sector in South Africa. In A National Waste RDI Roadmap for South Africa: Phase 1 Status Quo Assessment; Department of Science and Technology: Pretoria, South African, 2013. Available online: http:/ / wasteroadmap.co.za/download/waste_sector_survey_2012.pdf (accessed on 2 October 2017).

35. DEA (Department of Environmental Affairs). Report on the Determination of the Extent and Role of Waste Picking in South Africa; DEA: Pretoria, South Africa, 2016. Available online: http:/ / sawic.environment.gov. za/documents/5413.pdf (accessed on 2 October 2017).

36. Linzner, R.; Lange, U. Role and size of informal sector in waste management-A review. Waste Resour. Manag. 2013, 166, 69-83. [CrossRef]

37. DTI (Department of Trade and Industry). The integrated strategy on the promotion of co-operatives: Promoting an integrated co-operative sector in South Africa. In Select Committee on Trade and International Relations; DTI: Makati, Philippines, 9 February 2011. 
38. Godfrey, L.; Muswema, A.; Strydom, W.; Mamafa, T.; Mapako, M. Evaluation of co-operatives as a developmental vehicle to support job creation and SME development in the waste sector. Technical report: Case Studies. In Research and Policy Development to Advance a Green Economy in South Africa; CSIR Report CSIR/NRE/GES/IR/2015/0053/C; CSIR: Pretoria, South African, 2015. Available online: http:/ / www.sagreenfund.org.za/wordpress/wp-content/uploads/2016/04/GreenFundWaste-co-operatives-report_CSIR-final.pdf (accessed on 2 October 2017).

39. Godfrey, L.; Muswema, A.; Strydom, W.; Mamafa, T.; Mapako, M. Co-Operatives as a Development Mechanism to Support Job Creation and Sustainable Waste Management in South Africa. Sustain. Sci. 2017, 12, 799-812. [CrossRef]

40. NPC (National Planning Commission). National Development Plan. 2011. Available online: https:/ / www. gov.za/issues / national-development-plan-2030 (accessed on 2 October 2017).

41. Republic of South Africa. New Growth Path. 2010. Available online: http://www.economic.gov.za/ communications/publications/new-growth-path-series (accessed on 2 October 2017).

42. DTI (Department of Trade and Industry). Industrial Policy Action Plan; DTI: Pretoria, South African, 2010.

43. EDD (Economic Development Department). The Green Accord; EDD: Cape Town, South African, 2011.

44. DEA (Department of Environmental Affairs). National Waste Management Strategy; DEA: Pretoria, South Africa, 2011. Available online: https:/ /www.environment.gov.za/documents/strategicdocuments/ wastemanagement (accessed on 2 October 2017).

45. Republic of South Africa. National Climate Change Response Strategy White Paper. 2011. Available online: https://www.sanbi.org/sites/default/files/documents/documents/national-climatechange-response-white-paper.pdf (accessed on 2 October 2017).

46. DST (Department of Science and Technology). A Waste Research, Development and Innovation Roadmap for South Africa (2015-2025); Department of Science and Technology: Pretoria, South Africa, 2014. Available online: http:/ / wasteroadmap.co.za/roadmap/index.php (accessed on 2 October 2017).

47. Oelofse, S.H.H.; Godfrey, L. Defining waste in South Africa: Moving beyond the age of 'waste'. S. Afr. J. Sci. 2008, 104, 242-246. Available online: http:/ / www.scielo.org.za/scielo.php?script=sci_arttext\&pid=S003823532008000400001 (accessed on 2 October 2017).

48. Western Cape Government. Regulatory Impact Assessment (RIA) for the Waste Economy in the Western Cape. In the Impacts of Rules and Regulations in the Waste Sector on Businesses in the Western Cape: A Report on in-Depth Interviews and Case Studies; Western Cape Government: Cape Town, South Africa, 2014.

49. Oelofse, S. Study Material for the North-West University Honours in Environmental Science with Specialisation in Waste Management; Oelofse of the Council for Scientific and Industrial Research (CSIR): Pretoria, South Africa, 2017.

50. Republic of South Africa. National Pricing Strategy for Waste Management. Government Gazette No. 40200, Notice No. 904. 2016. Available online: http:/ / sawic.environment.gov.za/documents/5885.pdf (accessed on 2 October 2017).

51. Republic of South Africa. Amendments to the Waste Tyre Regulations. 2009. Government Gazette No. 40470, Notice No. 1493. 2016. Available online: http:/ / sawic.environment.gov.za/documents / 6344.pdf (accessed on 2 October 2017).

52. Republic of South Africa. Rates and Monetary Amounts and Amendment of Revenue Laws Act. Act No. 13 of 2016. Government Gazette No. 40560, Notice No. 38. 2017. Available online: http:/ / www.sars.gov.za/AllDocs/LegalDoclib / AmendActs/LAPD-LPrim-AA-2017-01\%20-\%20Rates\% 20and $\% 20$ Monetary $\% 20$ Amounts $\% 20$ and $\% 20$ Amendment $\% 20$ of $\% 20$ Revenue $\% 20$ Laws $\% 20$ Act $\% 20$ Act $\%$ 2013\%20of\%202016\%20GG\%2040560.pdf (accessed on 2 October 2017).

53. Republic of South Africa. Notice to Require the Tyre Industry to Prepare and Submit an Industry Waste Tyre Management Plan to the Minister for Approval; Government Gazette No. 40751, Notice No. 300. 31 March 2017. Available online: https:/ / www.gov.za/sites/default/files/40751_gon300.pdf (accessed on 18 October 2017).

(c) 2017 by the authors. Licensee MDPI, Basel, Switzerland. This article is an open access article distributed under the terms and conditions of the Creative Commons Attribution (CC BY) license (http:// creativecommons.org/licenses/by/4.0/). 